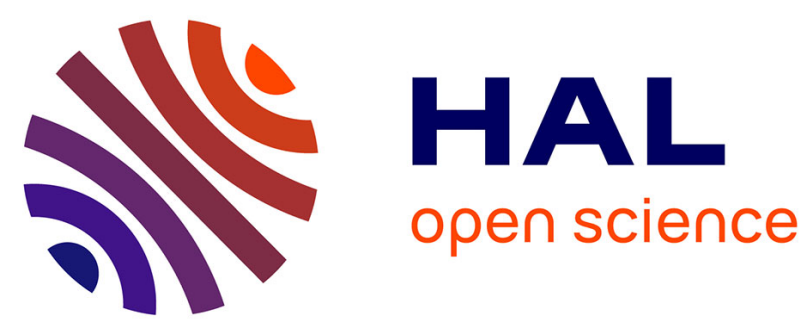

\title{
Metallophyte wastes and polymetallic catalysis: a promising combination in green chemistry. The illustrative synthesis of 59-capped RNA3
}

Yann Thillier, Guillaume Losfeld, Vincent Escande, Christelle Dupouy, Jean-Jacques Vasseur, Françoise Debart, Claude Grison

\section{To cite this version:}

Yann Thillier, Guillaume Losfeld, Vincent Escande, Christelle Dupouy, Jean-Jacques Vasseur, et al.. Metallophyte wastes and polymetallic catalysis: a promising combination in green chemistry. The illustrative synthesis of 59-capped RNA3. RSC Advances, 2013, 3 (15), pp.5204-5212. 10.1039/C3RA23115A . hal-03173870

\author{
HAL Id: hal-03173870 \\ https://hal.science/hal-03173870
}

Submitted on 18 Mar 2021

HAL is a multi-disciplinary open access archive for the deposit and dissemination of scientific research documents, whether they are published or not. The documents may come from teaching and research institutions in France or abroad, or from public or private research centers.
L'archive ouverte pluridisciplinaire HAL, est destinée au dépôt et à la diffusion de documents scientifiques de niveau recherche, publiés ou non, émanant des établissements d'enseignement et de recherche français ou étrangers, des laboratoires publics ou privés. 


\title{
Metallophyte wastes and polymetallic catalysis: a promising combination in green chemistry. The illustrative synthesis of 5'-capped RNA $\dagger$
}

\author{
Yann Thillier, ${ }^{a}$ Guillaume Losfeld, ${ }^{\mathrm{b}}$ Vincent Escande, ${ }^{\mathrm{b}}$ Christelle Dupouy, ${ }^{\mathrm{a}}$ Jean- \\ Jacques Vasseur, ${ }^{a}$ Françoise Debart*a and Claude Grison*b
}

\begin{abstract}
The compatibility of metallic catalysts derived from plants was studied for the chemical solid-phase synthesis of a high added-value biomolecule: $5^{\prime}$-capped RNA (GpppRNA or ${ }^{7 m}$ GpppRNA) involved in many essential biological processes. These molecules are of great interest for biologists for structural and mechanistic studies of their complexes with RNA capping enzymes. Several polymetallic catalysts were prepared from various metallophytes species growing in mine sites in a context of phytoremediation programs. Their catalytic efficacy was evaluated for the coupling reaction of guanosine diphosphate (GDP) with a preactivated 5'-monophosphate hexathymidylate $\left(\mathrm{pT}_{6}\right)$ or a pRNA to form $5^{\prime}-\mathrm{GpppT}_{6}$ or $5^{\prime}$-GpppRNA respectively. The direct coupling of ${ }^{7 m}$ GDP with pRNA was also investigated. With $\mathrm{Zn}$ enriched catalysts obtained from Zn metallophytes, the capping yields were better than those obtained with conventional catalyst $\mathrm{ZnCl}_{2}$. Interestingly with $\mathrm{Ni}$-enriched plant extracts the yield was higher than with $\mathrm{NiCl}_{2}$, a polymetallic catalysis was certainly involved. With this plant-inspired catalysis, metallophytes wastes become efficient and greener polymetallic catalysts. Finally, environmental benefits and effectiveness can be combined.
\end{abstract}

\section{Introduction}

The concept of green chemistry holds great promise for reducing the negative environmental impacts of organic synthesis. The use of chemical processes designed to reduce waste products, to facilitate efficient reuse and recycling, to optimize high atom-economy, and to use reagents that are less hazardous to human health and the environment have contributed to significant advances in the development of clean processing pathways. The search for starting materials derived from renewable resources and abundant bio-based materials are among the relevant strategies under development in chemistry today. However, green chemistry implies contributing to solving or mitigating environmental problems as well as improving industrial efficiency. It can play a key role in this area for example through the development of innovative solutions.

The European Environmental Agency estimates that 3 million sites in European Union countries are polluted. The

a IBMM, UMR 5247 CNRS-UM1-UM2, Université Montpellier 2, cc1704, Place Eugène Bataillon, 34095 Montpellier cedex 5 France. E-mail: debart@univ-montp2.fr; Fax: (+)334670420 29; Tel: (+)33467143898

${ }^{b}$ Centre d'Ecologie Fonctionnelle et Evolutive UMR CNRS 5175, 1919 Route de Mende F34293 Montpellier cedex 5 France.E-mail: claude.grison@cefe.cnrs.fr;

Fax: (+)334676133 16; Tel: (+)33467613316 most common harmful contaminants are heavy metals. The discovery of metal hyperaccumulator plants able to extract and concentrate heavy metals from contaminated soils in their leaves and shoots provides an attractive opportunity to remove them from polluted soils and ecosystems. The use of such plants has led to the development of various phytoextraction techniques. $^{1-5}$ Today, using vascular plants to 'clean up' the environment may potentially be used in large-scale costeffective projects, and have a high degree of public approval. ${ }^{6-9}$ Benefits for the environment and for human health are well quantified. This has resulted in a clear European-wide call for greater efforts to be made in ecological remediation and restoration of polluted sites. However, the financial aspect of phytoextraction remains a difficulty, because existing techniques of phytotechnology lack real economic outlets, and thus the costs outweigh the economic benefits. In other words, there is no clear business case for industrial stakeholders and public funds are not currently made available for this purpose.

Our previous research has demonstrated that phytoextraction of heavy metals can constitute the starting point of an original and attractive approach for 'green' or 'environmentally-friendly' heterogeneous catalysis. ${ }^{10-12}$ Notably, the synthetic potential of these new systems was illustrated through model reactions of industrial interest, Friedel-Crafts and Lucas reactions. In the present contribution, we demonstrate that these novel, 'bio-inspired' metallic catalysts promote the 


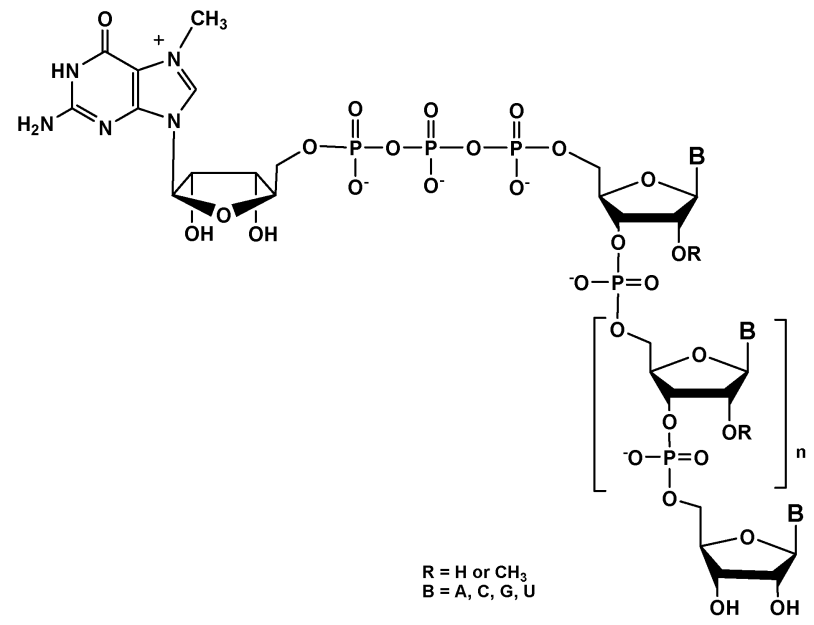

Fig. 1 mRNA cap structure ${ }^{7 m} \mathrm{Gppp}$

synthesis of high added-value molecules characterized by structural complexity. A key example is the chemical functionalization of RNA with cap structures at their $5^{\prime}$-end (Fig. 1). The cap moiety consists of a $N^{7}$-methylguanosine nucleoside $\left({ }^{7 \mathrm{~m}} \mathrm{GpppN}\right)$ linked to the $5^{\prime}$-terminal nucleoside of the premRNA via a $5^{\prime}-5^{\prime}$ triphosphate bond. ${ }^{13,14}$ This modification is critical for efficient translation,,${ }^{15}$ for limiting RNA degradation by cellular $5^{\prime}$ exonucleases and for avoiding recognition of mRNA as "nonself" by the innate immunity machinery. ${ }^{16}$ Convenient access and availability of large quantities of capped RNA ( $\left.{ }^{7 \mathrm{~m}} \mathrm{GpppRNA}\right)$ are of great interest for biologists for structural and mechanistic studies of their complexes with RNA capping enzymes. In vitro enzymatic methods cannot produce sufficient amounts of ${ }^{7 \mathrm{~m}} \mathrm{GpppRNA}$ of defined sequences. Although a few chemical methods had been described, most of them produce a very limited amount of capped RNA. ${ }^{17,18}$ Therefore the need of an universal and efficient method to obtain these synthetic RNA in significant quantities and high purity was critical. To overcome this bottleneck, we have recently developed an efficient strategy for the production of capped RNA with high yields and without any limitation concerning the nucleotide present at the $5^{\prime}$-end of the RNA substrate. ${ }^{19}$ This consists in the combination of chemical solid-phase synthesis of GpppRNA followed by enzymatic $N^{7}$-methylation. In this method, the functionalization at $5^{\prime}$-end of RNA with the cap structure involves the use of zinc chloride for the coupling reaction of guanosine diphosphate (GDP) with a preactivated 5'-monophosphate oligonucleotide to form GpppRNA. Here we report on the capping reaction using innovative and various metal chlorides, which are derived from different metallophyte species to functionalize RNA at their $5^{\prime}$-end with the cap structures Gppp or ${ }^{7 \mathrm{~m}}$ Gppp (Fig. 1). Furthermore for the first time we describe a straightforward chemical synthesis to obtain ${ }^{7 \mathrm{~m}}$ GpppRNA. The compatibility of bio-based catalysts was studied for the chemical synthesis of various lengths and sequences of natural and chemical modified DNA and RNA.

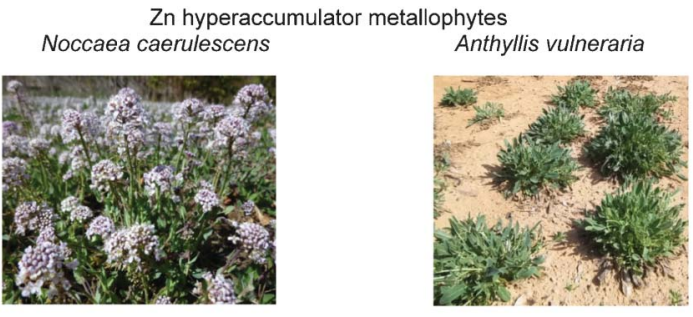

Ni hyperaccumulator metallophytes

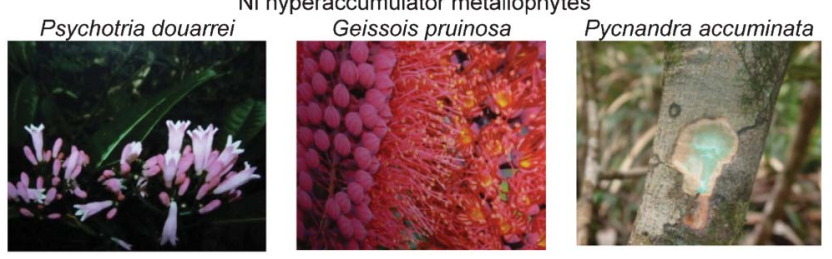

Fig. 2 Metallophytes species for polymetallic catalysis.

\section{Results and discussion}

Green polymetallic catalysts derived from various metallophytes species: preparation and analysis

The selection of hyperaccumulator plants was undertaken in the context of our ongoing phytoremediation programs (Fig. 2). Zn hyperaccumulating leaves were derived from Noccaea caerulescens and Anthyllis vulneraria. They were collected from plants growing on the Les Avinières mine site, at Saint-Laurent-Le-Minier (Gard) in the Mediterranean climate region of southern France. Ni hyperaccumulating leaves were derived from Psychotria douarrei, Geissois pruinosa and Pycnandra accuminata. They were collected from plants growing in the Southern Province of the subtropical Pacific island of New Caledonia.

Leaves were harvested before flowering, air-dried and crushed. The obtained solid was calcined at $400{ }^{\circ} \mathrm{C}$ for $5 \mathrm{~h}$ and the resulting powder was added to a $5 \mathrm{M} \mathrm{HCl}$ solution. After heating the mixture at $60{ }^{\circ} \mathrm{C}$ for $2 \mathrm{~h}$, then filtration on celite, the resulting solutions, composed of different metal chlorides, were then concentrated under vacuum. Dry residues were either used crude or partially purified in order to decrease the concentration of alkali and alkaline earth metals in the catalytic solid. When Ni hyperaccumulating metallophytes (P. douarrei and G. pruinosa) were used, a chelating resin allowed $\mathrm{Ni}$ concentration and partial elimination of undesired metals ions. Thus, elution of alkali and alkaline earth metals was performed with $\mathrm{HCl}$ at $\mathrm{pH} 2.5$ whereas transition metals were eluted with $12 \mathrm{M} \mathrm{HCl}$. With $\mathrm{Zn}$ hyperaccumulating metallophytes ( $N$. caerulescens and $A$. vulneraria), IRA 400 ion exchange resin was considered and its use resulted in adsorption of $\mathrm{Zn}^{\mathrm{II}}$ on the resin, and elution of alkali and alkaline earth cations.

Treatment with $0.5 \mathrm{M} \mathrm{HCl}$ eliminated a part of $\mathrm{Fe}^{\mathrm{III}}$ fixed on the resin before the elution of heavy metals $\left(\mathrm{Zn}^{\mathrm{II}}, \mathrm{Cd}^{\mathrm{II}}, \mathrm{Pb}^{\mathrm{II}}\right)$ with $0.005 \mathrm{M} \mathrm{HCl}$. Inductively coupled plasma mass spectrometry (ICP-MS) was used to determine the composition of the various plant extracts obtained. Detailed results are presented in Table 1. 


\begin{tabular}{|c|c|c|c|c|c|c|c|c|c|c|c|}
\hline \multirow[b]{2}{*}{ Entry } & \multirow[b]{2}{*}{ Catalysts } & \multicolumn{10}{|c|}{ Concentration (ppm) } \\
\hline & & $\mathrm{Mg}$ & $\mathrm{Al}$ & $\mathrm{Ca}$ & Mn & $\mathrm{Fe}$ & $\mathrm{Ni}$ & $\mathrm{Cu}$ & $\mathrm{Zn}$ & $\mathrm{Cd}$ & $\mathrm{Pb}$ \\
\hline & N. caerulescens extract & & & & & & & & & & \\
\hline 1 & -crude & 34769 & 10294 & 330362 & 594 & 11448 & 584 & 409 & 89157 & 7119 & 21050 \\
\hline 2 & -purified (fraction 1) & 49513 & 209 & 358327 & 190 & 1002 & 506 & 58 & 524 & 140 & 131 \\
\hline 3 & $\begin{array}{l}\text {-purified (fraction } 3 \text { ) } \\
\text { N. caerulescens }+ \\
\text { A. vulneraria extract }\end{array}$ & 30130 & 8530 & 180873 & 3598 & 30740 & 3598 & 655 & 405477 & 6400 & 36078 \\
\hline 4 & $\begin{array}{l}\text {-crude } \\
\text { P. douarrei extract }\end{array}$ & 28202 & 14878 & 134925 & 936 & 27275 & 2985 & 523 & 91232 & 4845 & 29249 \\
\hline 5 & -crude & 20768 & 5419 & 96731 & 1402 & 5570 & 80153 & 299 & 7902 & 80 & 703 \\
\hline 6 & $\begin{array}{l}\text {-purified } \\
\text { G. pruinosa extract }\end{array}$ & 22320 & 2250 & 91212 & 1596 & 2808 & 184600 & 401 & 6863 & 131 & 942 \\
\hline 7 & -crude & 76265 & 5302 & 119756 & 1066 & 7882 & 73863 & 551 & 12524 & 215 & 2808 \\
\hline 8 & $\begin{array}{l}\text {-purified } \\
P . \text { accuminata extract }\end{array}$ & 31969 & 4764 & 87667 & 3155 & 4589 & 150395 & 406 & 9597 & 153 & 2083 \\
\hline 9 & -crude & 22519 & 4002 & 40659 & 1399 & 5791 & 115163 & 115 & 2344 & 224 & 1393 \\
\hline
\end{tabular}

According to Pearson's HSAB (hard and soft (Lewis) acids and bases) principle, the catalytic solids generated from metallophytes led to modulation of the hard/soft ratio. The obtained catalytic solids could be distinguished according to three types of Lewis acid level: the purified $N$. caerulescens extract, called fraction 1 (Table 1, entry 2), led to a Pearson's "Hard Lewis Acid" mixture, because the $\mathrm{Mg}^{2+}, \mathrm{Ca}^{2+}, \mathrm{Al}^{3+}, \mathrm{Fe}^{3+}$ contribution represented $99.6 \%$ of the cationic mixture.

Purified N. caerulescens extract, called fraction 3 (Table 1, entry 3), purified $P$. douarrei (Table 1, entry 6) and G. pruinosa (Table 1, entry 8) extracts led to a Pearson's “Borderline Lewis Acid" composition, with a mixture of borderline and soft Lewis acids $\left(\mathrm{Mn}^{2+}+\mathrm{Ni}^{2+}+\mathrm{Cu}^{2+}+\mathrm{Zn}^{2+}+\mathrm{Cd}^{2+}+\mathrm{Pb}^{2+}=62,64,66 \%\right)$. Crude extracts were constituted by miscellaneous cations composition with respect to Pearson's classification system.

\section{Chemical synthesis of hexathymidylate with $5^{\prime}$-cap structure (GpppT $_{6}$ ) (Table 2, entries 1-12)}

Before the capping reaction on RNA sequences of biological interest, we tested various catalytic metals derived from metallophyte species with a DNA homosequence as a model. Therefore we initiated the study with the synthesis of 5 '-guanosyl triphosphate hexa-2'-deoxythymidylate $\left(\mathrm{GpppT}_{6}\right)$ 5, which was prepared at $1 \mu \mathrm{mol}$ scale on solid support following the same route (Scheme 1) as recently described. ${ }^{19}$ The solid-supported $\mathrm{T}_{6} \mathbf{1}$ was assembled by the standard automated phosphoramidite method using a controlled pore glass support (CPG). After elongation, $\mathrm{T}_{6} \mathbf{1}$ was converted into its $5^{\prime}-H$-phosphonate derivative 2 which was activated as its phosphoroimidazolidate $\mathbf{3}$ by amidative oxidation with quantitative yield.

The key step is the coupling between the commercial guanosine diphosphate (GDP) and hexathymidinyl 5'-phosphoroimidazolidate 3 linked to the solid support. The general mechanism is based on a nucleophilic attack of the GDP phosphoryl moiety on the $5^{\prime}$-phosphoramidate 3 displacing the imidazolide group. The ideal conditions to obtain the triphosphate bond were satisfied if:

-unprotected and poorly soluble GDP sodium salt in organic solvent was converted into GDP bis(tri- $n$-butylammonium) to pass into solution by association with a divalent metal chloride;

-the metal salt activated phosphoramidate 3 to enhance the coupling reaction with GDP;

-the activation conditions should be compatible with fragility of the GDP and the formed triphosphate bridge.

Among several divalent metal salts, $\mathrm{ZnCl}_{2}$ in anhydrous DMF has been found to be the most efficient. This result illustrated the interest of Pearson's "Borderline Lewis Acids" in this reaction. However, the reaction remains quite a delicate problem. This could be accomplished by careful and delicate reaction condition control and moderate yields. In the context of our investigations, we aimed to improve the reaction efficiency with our 'eco-friendly' and non-conventional catalysts. From a statistical point of view, it appeared reasonable to expect that a mixture of different metal halides could better interact with three distinct coordination sites than a single metal cation; consequently, a polymetallic catalyst could strongly promote the reaction sequence.

Substitution of the imidazole by GDP $(0.14 \mathrm{mmol})$ was successfully accomplished at $30{ }^{\circ} \mathrm{C}$ for $18 \mathrm{~h}$ in dry DMF in the presence of a divalent metal salt $(0.2 \mathrm{mmol})$ to give the capped $\mathrm{GpppT}_{6} 4$ still anchored to the solid support $(1 \mu \mathrm{mol})$. After removal of the capping solution from the synthesis reactor using a mix of water and EDTA followed by several washes with $\mathrm{CH}_{3} \mathrm{CN}$, the capped $\mathrm{GpppT}_{6}$ were deprotected and released from solid support. First, cyanoethyl groups were eliminated from the phosphates with $1 \mathrm{M}$ 1,8-diazabicyclo[5.4.0] undec-7ene (DBU) solution in dry $\mathrm{CH}_{3} \mathrm{CN}$ for $3 \mathrm{~min}$. Then, treatment with $30 \%$ aqueous ammonia at room temperature cleaved $\mathrm{GpppT}_{6} 5$ from the CPG support. The conversion yields of $\mathrm{T}_{6}$ into the desired capped $\mathrm{GpppT}_{6}$ were calculated by integration of the major peaks corresponding to the capped $\mathrm{T}_{6}$ in the ionexchange HPLC chromatograms of the crude materials (Fig. 3).

The capping yield could reach up to 66\% (Table 2, entry 6). Further characterization was completed by MALDI-TOF mass spectrometry (Table 2).

A global analysis shows the interest of these new systems to facilitate catalysis during the coupling reaction. All crude extracts allowed the complete dissolution of GDP and 
Table 2 Data for synthesized 5'-GpppT $6,5^{\prime}-$ GpppRNAs and $5^{\prime}-{ }^{7 m}$ GpppRNAs

\begin{tabular}{|c|c|c|c|c|c|c|c|c|}
\hline Entry & Catalysts $^{a}$ & $5^{\prime}$-sequence-3' & Yield $(\%)^{b}$ & Crude yield ${ }^{c}$ & Isolated yield ${ }^{d}$ & Molecular formula & Calc. $m / z^{e}$ & Found $m / z^{e}$ \\
\hline 1 & $\mathrm{ZnCl}_{2}$ & $\mathrm{GpppT}_{6}$ & 55 & 498 & nd & $\mathrm{C}_{70} \mathrm{H}_{93} \mathrm{~N}_{17} \mathrm{O}_{57} \mathrm{P}_{8}$ & 2267.35 & 2267.29 \\
\hline 2 & $\mathrm{NiCl}_{2}$ & $\mathrm{GpppT}_{6}$ & 26 & 421 & nd & $\mathrm{C}_{70} \mathrm{H}_{93} \mathrm{~N}_{17} \mathrm{O}_{57} \mathrm{P}_{8}$ & 2267.35 & 2267.61 \\
\hline \multicolumn{9}{|c|}{ N. caerulescens extract (Zn-enriched) } \\
\hline 3 & crude & $\mathrm{GpppT}_{6}$ & 31 & 430 & nd & $\mathrm{C}_{70} \mathrm{H}_{93} \mathrm{~N}_{17} \mathrm{O}_{57} \mathrm{P}_{8}$ & 2267.35 & 2267.34 \\
\hline 4 & purified (f1) & $\mathrm{GpppT}_{6}$ & 0 & 351 & nd & $\mathrm{C}_{70} \mathrm{H}_{93} \mathrm{~N}_{17} \mathrm{O}_{57} \mathrm{P}_{8}$ & 2267.35 & - \\
\hline 5 & purified (f3) ${ }^{f}$ & $\mathrm{GpppT}_{6}$ & 55 & 487 & nd & $\mathrm{C}_{70} \mathrm{H}_{93} \mathrm{~N}_{17} \mathrm{O}_{57} \mathrm{P}_{8}$ & 2267.35 & 2267.25 \\
\hline 6 & purified (f3) & $\mathrm{GpppT}_{6}$ & 66 & 512 & nd & $\mathrm{C}_{70} \mathrm{H}_{93} \mathrm{~N}_{17} \mathrm{O}_{57} \mathrm{P}_{8}$ & 2267.35 & 2267.65 \\
\hline \multicolumn{9}{|c|}{$N$. caerulescens $+A$. vulneraria extract } \\
\hline 7 & crude & $\mathrm{GpppT}_{6}$ & 6 & 402 & nd & $\mathrm{C}_{70} \mathrm{H}_{93} \mathrm{~N}_{17} \mathrm{O}_{57} \mathrm{P}_{8}$ & 2267.35 & 2267.57 \\
\hline \multicolumn{9}{|c|}{ P. douarrei extract (Ni-enriched) } \\
\hline 8 & crude & $\mathrm{GpppT}_{6}$ & 26 & 437 & nd & $\mathrm{C}_{70} \mathrm{H}_{93} \mathrm{~N}_{17} \mathrm{O}_{57} \mathrm{P}_{8}$ & 2267.35 & 2267.36 \\
\hline 9 & purified $^{f}$ & $\mathrm{GpppT}_{6}$ & 56 & 378 & nd & $\mathrm{C}_{70} \mathrm{H}_{93} \mathrm{~N}_{17} \mathrm{O}_{57} \mathrm{P}_{8}$ & 2267.35 & 2267.80 \\
\hline \multicolumn{9}{|c|}{ G. pruinosa extract (Ni-enriched) } \\
\hline 10 & crude & $\mathrm{GpppT}_{6}$ & 18 & 423 & nd & $\mathrm{C}_{70} \mathrm{H}_{93} \mathrm{~N}_{17} \mathrm{O}_{57} \mathrm{P}_{8}$ & 2267.35 & 2267.34 \\
\hline 11 & purified & $\mathrm{GpppT}_{6}$ & 42 & 461 & nd & $\mathrm{C}_{70} \mathrm{H}_{93} \mathrm{~N}_{17} \mathrm{O}_{57} \mathrm{P}_{8}$ & 2267.35 & 2267.29 \\
\hline \multicolumn{9}{|c|}{ P. accuminata extract (Ni-enriched) } \\
\hline 12 & crude & $\mathrm{GpppT}_{6}$ & 33 & 456 & nd & $\mathrm{C}_{70} \mathrm{H}_{93} \mathrm{~N}_{17} \mathrm{O}_{57} \mathrm{P}_{8}$ & 2267.35 & 2267.19 \\
\hline 13 & $\mathrm{ZnCl}_{2}$ & GpppAGUUGUUAGUCUUACUGG & 46 & 331 & 73 & $\mathrm{C}_{151} \mathrm{H}_{225} \mathrm{~N}_{70} \mathrm{O}_{141} \mathrm{P}_{20}$ & 6254.57 & 6254.86 \\
\hline 14 & $\mathrm{ZnCl}_{2}$ & GpppAUAUUA & 45 & 408 & 138 & $\mathrm{C}_{67} \mathrm{H}_{83} \mathrm{~N}_{26} \mathrm{O}_{53} \mathrm{P}_{8}$ & 2348.31 & 2348.32 \\
\hline 15 & $\mathrm{ZnCl}_{2}$ & ${ }^{7 \mathrm{~m}}$ GpppAUAUUA & 38 & 303 & 89 & $\mathrm{C}_{68} \mathrm{H}_{85} \mathrm{~N}_{26} \mathrm{O}_{53} \mathrm{P}_{8}$ & 2362.34 & 2362.67 \\
\hline \multicolumn{9}{|c|}{ N. caerulescens extract (Zn-enriched) } \\
\hline 16 & purified (f3) & GpppA $_{\text {OMe }}$ GUUGUUAGUCUUACUGGA & 43 & 491 & 92 & $\mathrm{C}_{192} \mathrm{H}_{239} \mathrm{~N}_{75} \mathrm{O}_{145} \mathrm{P}_{21}$ & 6597.80 & 6597.45 \\
\hline 17 & purified (f3) & GpppAUAUUA & 32 & 372 & 102 & $\mathrm{C}_{67} \mathrm{H}_{83} \mathrm{~N}_{26} \mathrm{O}_{53} \mathrm{P}_{8}$ & 2348.31 & 2348.15 \\
\hline 18 & purified (f3) ${ }^{g}$ & ${ }^{7 \mathrm{~m}}$ GpppAUAUUA & 33 & 312 & 54 & $\mathrm{C}_{68} \mathrm{H}_{85} \mathrm{~N}_{26} \mathrm{O}_{53} \mathrm{P}_{8}$ & 2362.34 & 2362.59 \\
\hline \multicolumn{9}{|c|}{ P. douarrei extract (Ni-enriched) } \\
\hline 19 & purified & GpppA $_{\text {OMe GUUGUUAGUCUUACUGGA }}$ & 34 & 422 & 81 & $\mathrm{C}_{192} \mathrm{H}_{239} \mathrm{~N}_{75} \mathrm{O}_{145} \mathrm{P}_{21}$ & 6597.80 & 6597.03 \\
\hline 20 & purified & GpppAUAUUA & 23 & 344 & 73 & $\mathrm{C}_{67} \mathrm{H}_{83} \mathrm{~N}_{26} \mathrm{O}_{53} \mathrm{P}_{8}$ & 2348.31 & 2348.32 \\
\hline 21 & purified & ${ }^{7 \mathrm{~m}}$ GpppAUAUUA & 7 & 302 & nd & $\mathrm{C}_{68} \mathrm{H}_{85} \mathrm{~N}_{26} \mathrm{O}_{53} \mathrm{P}_{8}$ & 2362.34 & 2362.36 \\
\hline
\end{tabular}

${ }^{a}$ Final concentration in the reaction mixture of $\left[\mathrm{ZnCl}_{2}\right]=\left[\mathrm{NiCl}_{2}\right]=0.4 \mathrm{M}$ in DMF. ${ }^{b}$ Percentage yield of oligonucleotide in the crude as calculated from the integration of the IEX chromatogram. ${ }^{c}$ nmol crude total material. ${ }^{d}$ nmol pure product GpppRNA obtained after HPLC purification. nd: not determined. Oligonucleotides (entries 1-12, 20) were not HPLC purified. ${ }^{e}$ MALDI-TOF characterization in negative mode. ${ }^{f}$ The catalyst-GDP solution was not centrifuged, but the final mixture was eluted on Sephadex. ${ }^{g}$ The acidity of the catalyst was neutralized by refluxing the catalytic extract in dioxane to prevent depurination.

promoted the substitution of imidazolide (Table 2, entries 3, 8, 10 and 12 with $31 \%, 26 \%, 18 \%$ and $33 \%$ yield, respectively). Interesting results were obtained when the clear solution resulting from centrifugation of catalytic extracts and GDP in DMF had been applied (Table 2, entries 6 and 11 with $66 \%$ and $42 \%$ respectively). The ability of metallophyte extracts to perform catalysis depends critically on metal ion composition. Excluding the inactive fraction 1 derived from $N$. Caerulescens (Table 2, entry 4), all purified fractions (Table 2, entries 5, 6, 9, 11) led to comparable results to conventional catalysts $\mathrm{ZnCl}_{2}$ and $\mathrm{NiCl}_{2}$ (Table 2, entries 1 and 2). It is noteworthy that the purified fraction 3 derived from $N$. caerulescens (Table 2, entry 6) was better than commercial $\mathrm{ZnCl}_{2} \quad(66 \%$ and $55 \%$, respectively) (Fig. 3, Table 2, entries 1 and 3). Catalysts derived from Ni hyperaccumulating plants (Table 2, entries 8-12) should also be noted since $G$. pruinosa and $P$. douarrei led to expected products with satisfactory yields ranging from $42 \%$ (Table 2, entry 11) to $56 \%$ (Table 2, entry 9) whereas it is well known that $\mathrm{NiCl}_{2}$ is a poor acid-catalyst. Besides to date, no such capping reaction catalyzed by $\mathrm{NiCl}_{2}$ has ever been described.

Crude $P$. douarrei extract (Table 2, entry 8) had a similar catalytic activity to $\mathrm{NiCl}_{2}$ (Table 2, entry 2 ) with $26 \%$ coupling yield. Interestingly, despite of its weaker interest in our phytoremediation program for Ni-rich metallophytes, $P$. accuminata crude extract gave the best coupling yield (33\%). The $P$. douarrei and $G$. pruinosa purified extracts (Table 2, entries 9 and 11) were more active than commercial $\mathrm{NiCl}_{2}$. With the purified fraction issued of $P$. douarrei extract (Table 2, entry 9), the coupling yield with GDP was increased twice as much as compared with $\mathrm{NiCl}_{2}$ (56\% instead of $\left.26 \%\right)$ and reached the $55 \%$ yield obtained with $\mathrm{ZnCl}_{2}$ (Table 2, Fig. 3). It may be concluded that a synergetic effect exists between the present Lewis acids which improves catalytic performance, when a mixture of borderline and soft Lewis acids was made (purified extracts). These observations agree with Mikkola and et al., who found that a combination of two metal halides leads to more active systems than individual components in the $5^{\prime}$-cap nucleotides synthesis. ${ }^{20}$

As discussed above, their impact on catalysis is threefold. Thus, understanding the mechanisms underlying polymetallic catalysis is difficult. In order to learn more about these results, we have compared the ratio of expected and observed sideproducts for each of the catalytic compositions. Obtained results suggest that $\mathrm{Ni}$ metallophytes favoured $\mathrm{GppT}_{6}$ formation instead of the expected GpppT $_{6}$ (Table 3). So, it seems that Ni catalysts promote partial hydrolysis of GDP into GMP before coupling reaction. However the association of $\mathrm{Ni}$ and other metals, more efficient than sole $\mathrm{NiCl}_{2}$, can be explained by the binding of two metal ions to two adjacent Lewis base centers 

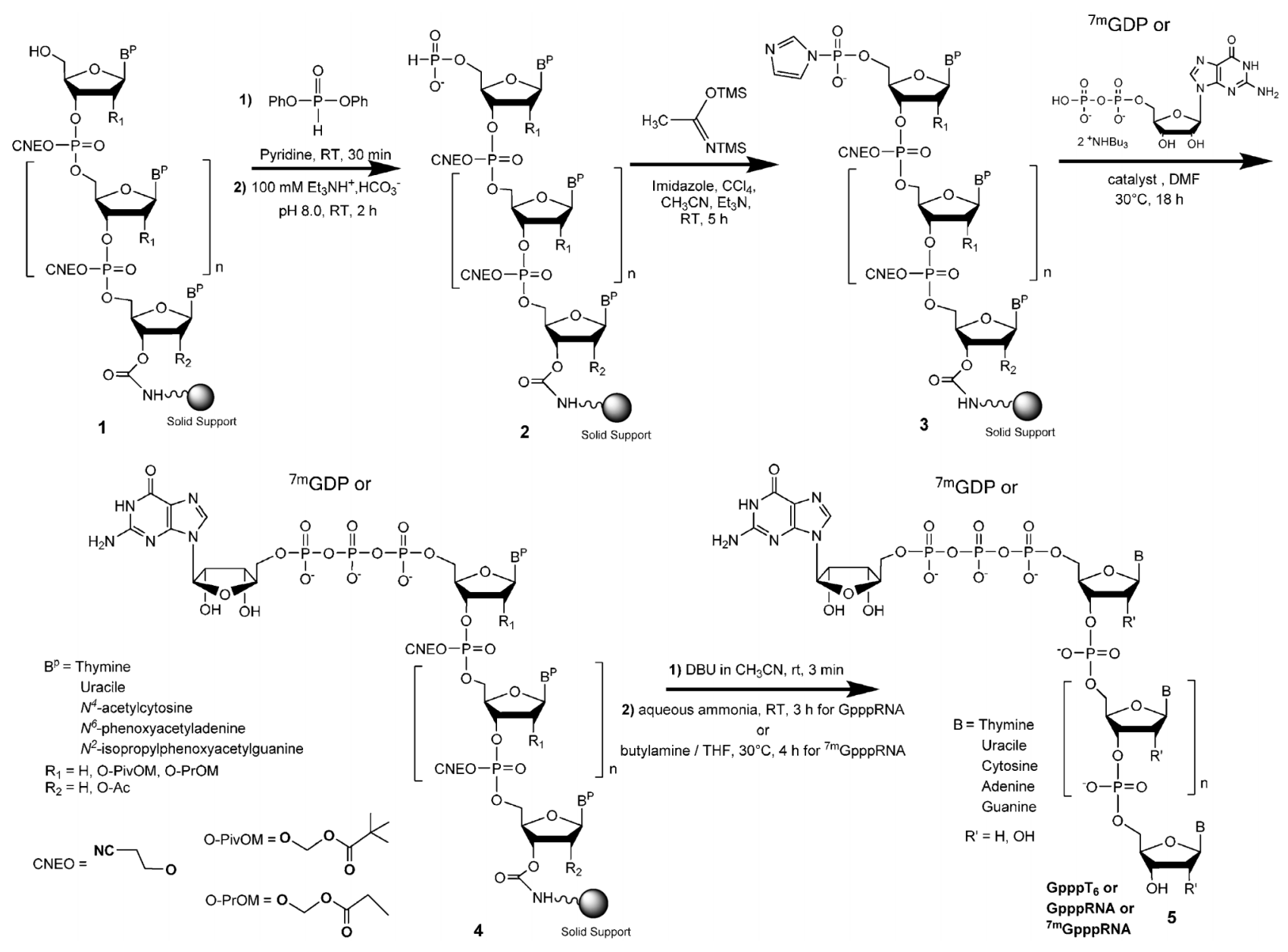

Scheme 1 Solid-phase synthesis of 5'-GpppT $6,5^{\prime}-G p p p R N A$ or $5^{\prime}-{ }^{7 m} G p p p R N A$.

of phosphoroimidazolidate 3 (Fig. 4). In view of the excellent affinity of the imidazole ring for $\mathrm{Ni}^{2+}$, we can suppose an interaction between the heterocycle and $\mathrm{NiCl}_{2}$, which strengthens the leaving group capacity of imidazole. This effect is added to the coordination between other metals and the phosphate group that increases electrophilicity of the activated phosphoryl ligand of $\mathbf{3}$. This double effect promotes the coupling reaction.

N. caerulescens $+A$. vulneraria crude extract (Table 2, entry 7 ) led to poor yield (6\%). This result can be correlated with the amount of $\mathrm{AlCl}_{3}$ (Table 1, entry 4). Finally, N. caerulescens purified extract (Table 2, fraction 1, entry 4) didn't promote the coupling reaction, since it is known that $\mathrm{Mg}^{2+}$ and $\mathrm{Ca}^{2+}$ have high affinity for the phosphate oxygen (Table 1, entry 2). Hard Lewis Acid mixture cannot activate the P-N bond. It can be concluded that essential cations for plant growth $\left(\mathrm{Na}^{\mathrm{I}}, \mathrm{K}^{\mathrm{I}}, \mathrm{Ca}^{\mathrm{II}}\right.$, $\left.\mathrm{Mg}^{\mathrm{II}}, \mathrm{Cu}^{\mathrm{II}}\right)$ are not useful in the aimed reaction, whereas $\mathrm{Zn}^{\mathrm{II}}$, $\mathrm{Ni}^{\mathrm{II}}, \mathrm{Cd}^{\mathrm{II}}$ and $\mathrm{Pb}^{\mathrm{II}}$ which result of heavy-metal hyperaccumulation promote the coupling reaction. Overall, these results show that the metallophyte species led to the preparation of an interesting polymetallic composition, which allowed coordination not only with the phosphate oxygen but also with the cyclic imidazole of the substrate.

\section{Chemical synthesis of RNA with 5 '-cap structure (GpppRNA or ${ }^{7 m}$ GpppRNA) (Table 2, entries 13-21)}

Encouraged by the efficiency of these catalysts, the reaction was extended to the synthesis of Gppp6-mers (Table 2, entries 14, 17, 20), Gppp19-mers (Table 2, entries 13, 16, 19) and ${ }^{7 \mathrm{~m}}$ Gppp6-mers (Table 2 , entries $15,18,21$ ) RNA heteropolymers with the two best catalytic systems: $N$. caerulescens and $P$. douarrei extracts.

Regarding the synthesis of $5^{\prime}$-capped RNA on solid support, the instability of $N^{7}$-methylguanosine under acidic and basic conditions and RNA sequence fragility are additional difficulties of the second part of this work. Indeed, because of the positive charge on the $N^{7}$-methylguanosine (Fig. 1), the nucleoside is hydrolytically less stable than standard purine nucleosides. Under basic conditions used for standard RNA deprotection, the opening of the imidazole ring of the 7-methylguanine would occur. For this reason, the synthesis of ${ }^{7 \mathrm{~m}} \mathrm{GpppRNA}$ completely achieved on solid support excludes the ammonia treatment to deprotect and to release ${ }^{7 m}$ GpppRNA. Therefore the strategy for RNA assembly to provide ${ }^{7 \mathrm{~m}}$ GpppRNA was different from the pivaloyloxymethyl (PivOM) technology used for RNA synthesis to get GpppRNA. ${ }^{21}$ The major feature of this technology developed by our group 

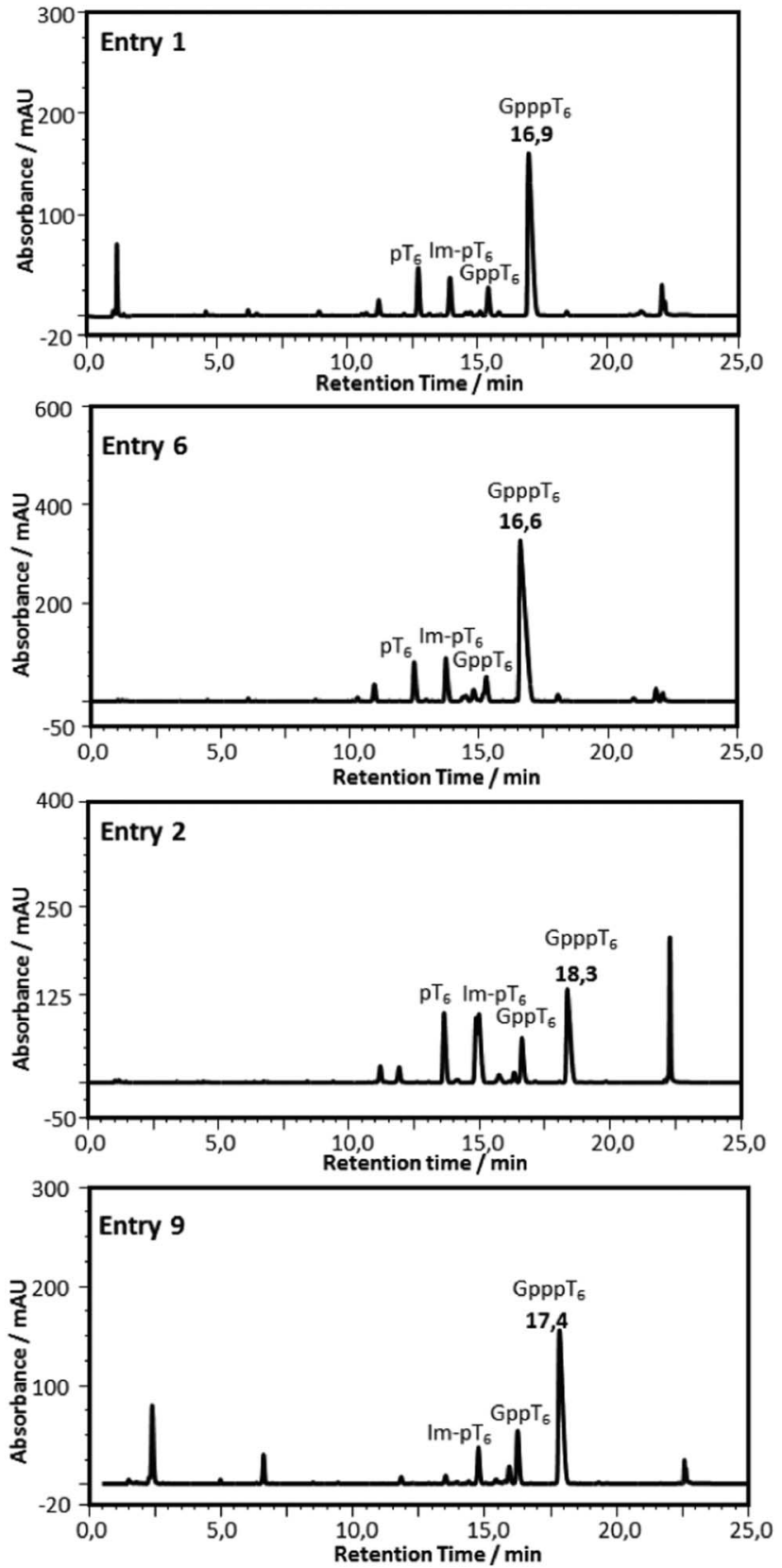

Fig. 3 Anion-exchange HPLC profiles of the crude mixture of $5{ }^{\prime}-G p p p T_{6}$ obtained with $\mathrm{ZnCl}_{2}$ (Table 2, entry 1), N. caerulescens purified extract (fraction 3) (Table 2, entry 6), $\mathrm{NiCl}_{2}$ (Table 2, entry 2 ) and with $P$. douarrei purified extract (Table 2, entry 9).

for RNA synthesis on solid support, is to use base-labile protecting groups exclusively removed under basic conditions without RNA damage. Thus, for GpppRNA synthesis (Table 2, entries 13, 14, 16, 17, 19, 20) RNA sequences were assembled on an automated synthesizer by the phosphoramidite solidphase method involving the base-labile $2^{\prime}$-O-PivOM groups. ${ }^{22}$ As for $\mathrm{T}_{6}$ sequences, after RNA elongation, the $5^{\prime}-\mathrm{OH}$ was converted into its phosphoroimidazolide 3 ready to react with GDP (Scheme 1) in the presence of purified catalysts derived from $N$. caerulescens and P. douarrei extracts. As shown for
Table 3 Comparison of the ratio of expected $\mathrm{GpppT}_{6}$ and observed sideproducts $\mathrm{GppT}_{6}$ depending on $\mathrm{Ni}$ composition of catalysts derived from $\mathrm{Ni}$ hyperaccumulating plants

\begin{tabular}{llll}
\hline Catalytic extracts & $\mathrm{GpppT}_{6}(\%)^{a}$ & $\mathrm{GppT}_{6}(\%)^{a}$ & $\mathrm{Ni}(\mathrm{ppm})$ \\
\hline $\begin{array}{l}\mathrm{NiCl}_{2} \\
\begin{array}{l}P \text {. douarrei extract } \\
\text {-crude }\end{array}\end{array}$ & 25 & 9 & 473684 \\
-purified & 26 & 3 & 80153 \\
$\begin{array}{l}\text { - pruinosa extract } \\
\text {-crude }\end{array}$ & 56 & 12 & 184600 \\
-purified & 18 & 3 & 73863 \\
$\begin{array}{l}\text { P. accuminata } \text { extract } \\
\text { - crude }\end{array}$ & 42 & 15 & 150395 \\
& 33 & 13 & 115163
\end{tabular}

${ }^{a}$ Percentage yield of oligonucleotide in the crude as calculated from the integration of the IEX chromatogram.

$\mathrm{GpppT}_{6}$ synthesis, the use of a clear solution resulting from centrifugation of catalytic extracts and GDP in DMF conditioned the success of the capping reaction. The purities of Gppp18-mers (Table 2, entry 16, 43\%) (Fig. 5) and Gppp6-mers (Table 2, entry $17,32 \%$ ) obtained with $N$. caerulescens were similar to the one with conventional catalyst $\mathrm{ZnCl}_{2}$ (entries 13 and $14,46 \%$ and $45 \%)$. With $P$. douarrei extract, the coupling yields of the same RNA sequences (Table 2, entries 19 and 20) with GDP were reasonably lower: $34 \%$ and $23 \%$, respectively.

Finally, we synthesized ${ }^{7 \mathrm{~m}}$ GpppAUA UUA (Table 2, entries 18 and 21) where as mentioned above the major difficulty is the fragility of $N^{7}$-methylguanine under basic or acidic conditions. RNA sequences were assembled using 2'-O-propyloxymethyl (PrOM) ribonucleosides amidites. ${ }^{23}$ This $2^{\prime}$-O-protecting group structurally closed to PivOM could be removed upon nucleophilic attack in dry organic solvent without using ammonia conditions which would lead to complete destruction of the $N^{7}$-methylguanine structure. After elongation on synthesizer, both RNA 6-mers were functionalized at their 5 '-end with a phosphoroimidazolide to react with ${ }^{7 \mathrm{~m}} \mathrm{GDP}$ bis(tri- $n$-butylam-

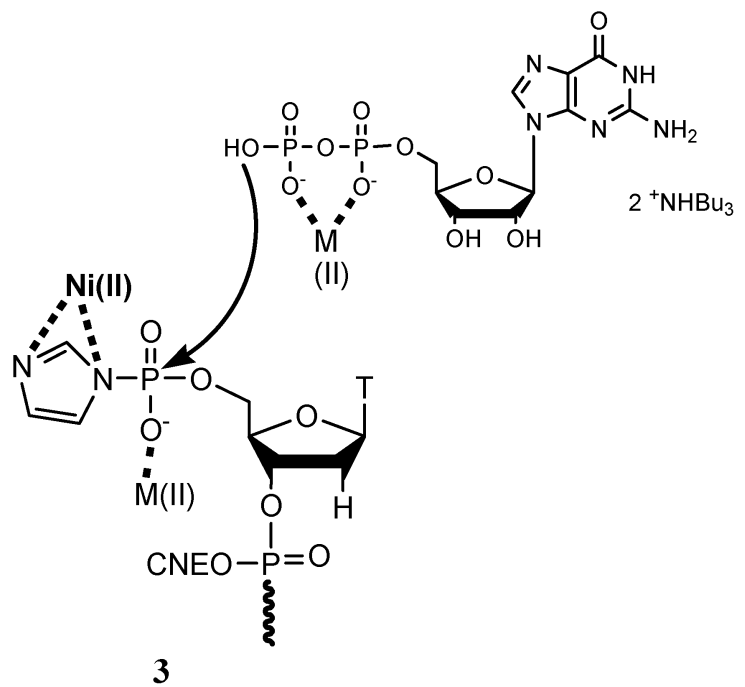

Fig. 4 Hypothetic mechanism for polymetallic participation in the coupling reaction. 

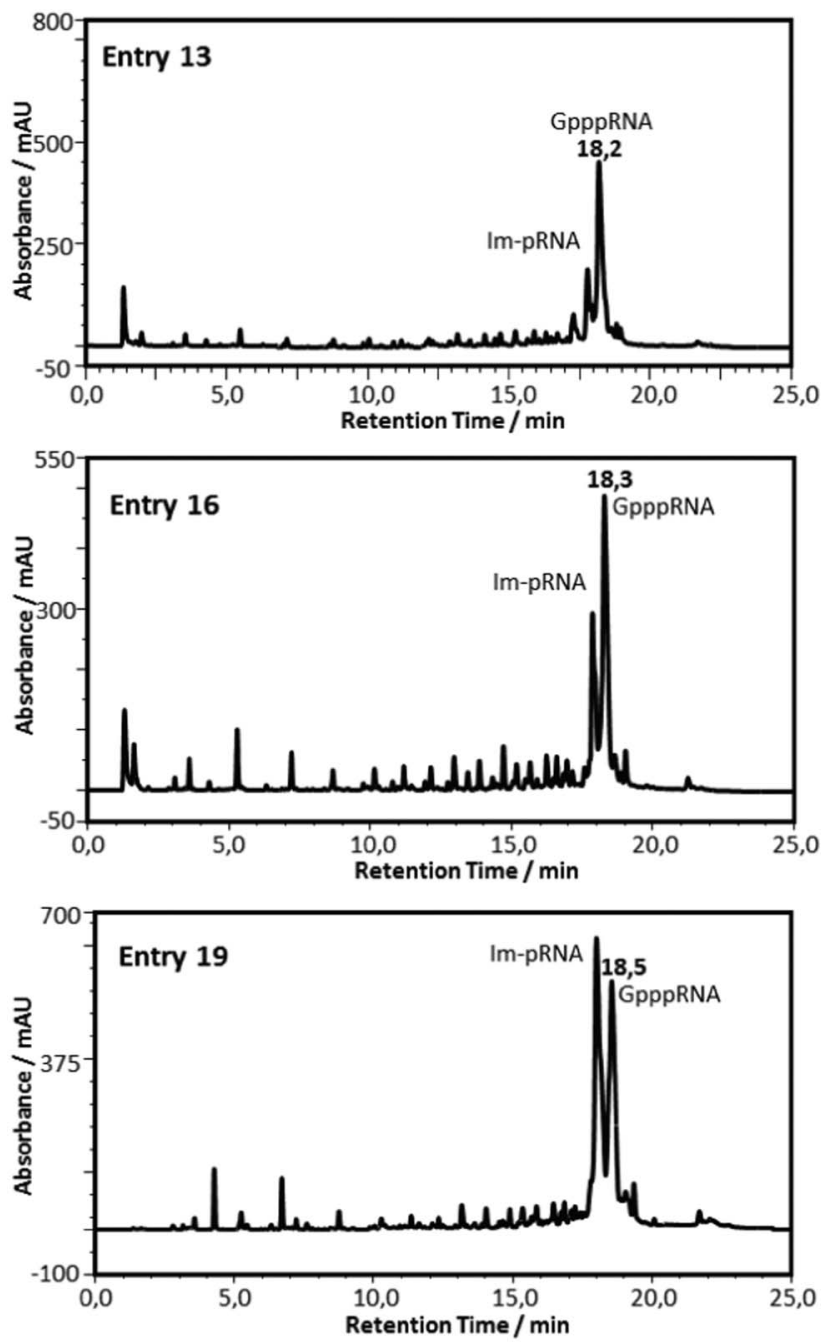

Fig. 5 Anion-exchange HPLC profiles of the crude mixture of

5'-GpppAGUUGUUAGUCUUACUGG obtained with $\mathrm{ZnCl}_{2}$ (Table 2, entry 13) and

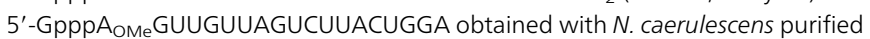
extract (fraction 3) (Table 2, entry 16) and with $P$. douarrei purified extract (Table 2, entry 19).

monium) in the presence of $\mathrm{ZnCl}_{2}$ (Table 2, entry 15), purified $N$. caerulescens (Table 2, entry 18) and $P$. douarrei extracts (Table 2, entry 21) (Scheme 1). First attempts in the same conditions previously used for GpppRNA were not successful and depurination of $N^{7}$-methylguanosine was observed which was confirmed by the disappearance of the peak in the HPLC profile monitored at $300 \mathrm{~nm}$ (characteristic wavelength of UV absorption of $\left.{ }^{7 \mathrm{~m}} \mathrm{G}\right){ }^{20}$ This major problem was certainly due to the presence of acidic traces in the catalytic extracts. When the acidity of catalyst derived from $N$. caerulescens (Table 2, entry 18) was neutralized by refluxing the catalytic extract in dioxane, the purity of ${ }^{7 \mathrm{~m}}$ GpppAUAUUA was acceptable (33\%) and near to $\mathrm{ZnCl}_{2}$ (38\%) (Fig. 6). It should be underlined that this is the first efficient all-chemical synthesis on solid support of an RNA with a ${ }^{7 \mathrm{~m}}$ cap structure and free $2^{\prime}-\mathrm{OH}$. Indeed only short $2^{\prime}$-OMe RNA bearing a ${ }^{7 \mathrm{~m}}$ cap were reported. ${ }^{18,24}$ Finally, with $P$. douarrei extract, the capping reaction was not as
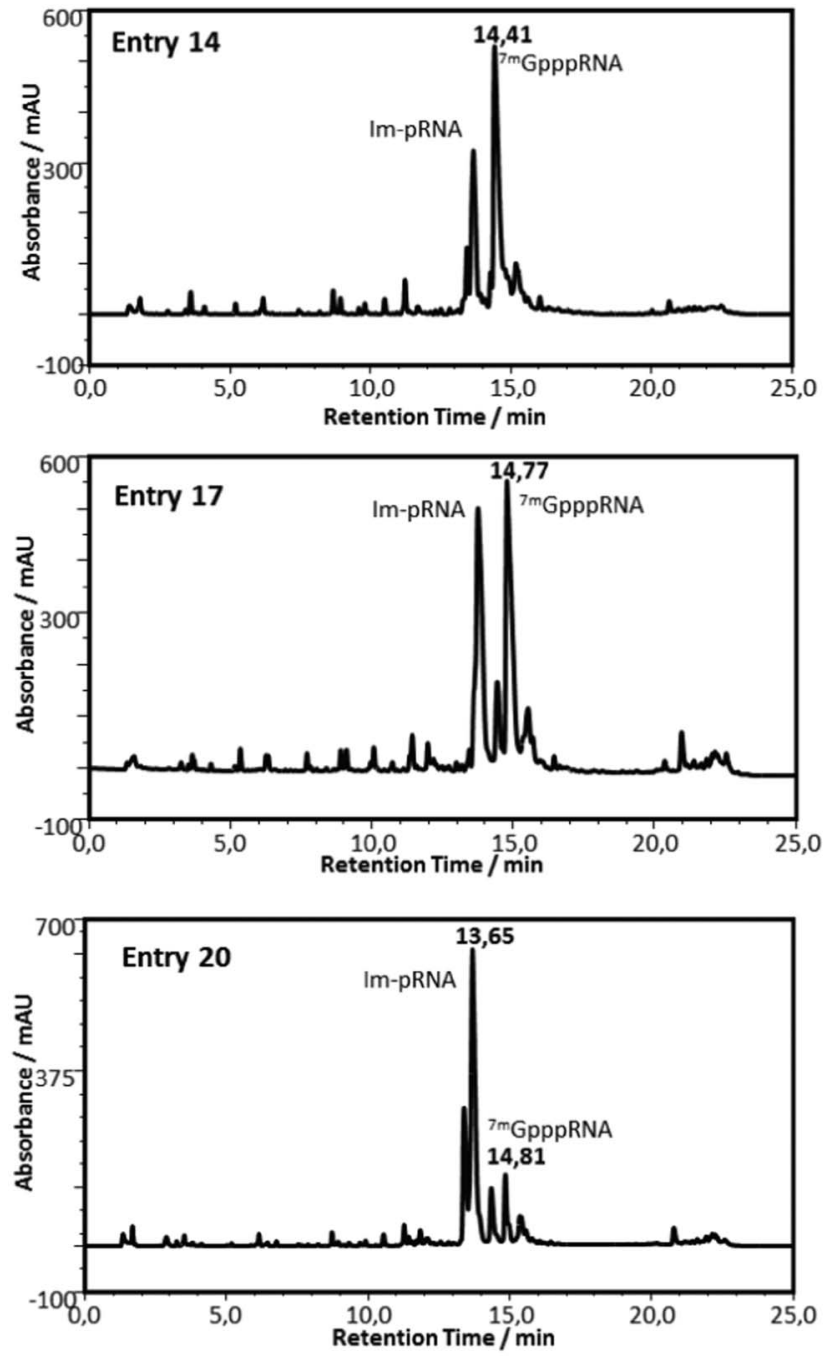

Fig. 6 Anion-exchange HPLC profiles of the crude mixture of $5^{\prime}-{ }^{7 m} \mathrm{GpppAUAUUA}$ obtained with $\mathrm{ZnCl}_{2}$ (Table 2, entry 14), with $\mathrm{N}$. caerulescens purified extract (fraction 3) (Table 2, entry 17) and with $P$. douarrei purified extract (Table 2, entry 20).

efficient as with $N$. caerulescens since the desired compound was present at $7 \%$ only in the reaction mixture.

\section{Experimental}

\section{Preparation of catalytic extracts from metallophytes species}

Leaves were harvested before flowering, air-dried and crushed. The obtained solid $(150 \mathrm{~g})$ was calcined at $400{ }^{\circ} \mathrm{C}$ for $5 \mathrm{~h}$ and the resulting powder ( $148 \mathrm{~g}$ ) was added to $1 \mathrm{~L}$ of a solution of 5 $\mathrm{M} \mathrm{HCl}$ solution. The solution was heated at $60{ }^{\circ} \mathrm{C}$ and stirred for $2 \mathrm{~h}$. The reaction mixture was filtered on celite. The resulting solutions, composed of different metal chlorides, were then concentrated under vacuum. Dry residues were either used crude or partially purified in order to decrease the concentration of alkali and alkaline earth metals in the catalytic solid. When Ni hyperaccumulating metallophytes $(P$. 
douarrei and $G$. pruinosa and $P$. accuminata) were used, a chelating resin such Dowex M4195, allowed Ni concentration and partial elimination on undesired metals ions. The catalytic solution was introduced on the uppermost surface of the Dowex M4195 (about $60 \mathrm{~g}$ of resin per gram of solid). Operating purification conditions were as follows: elution of alkali and alkaline earth metals with $\mathrm{HCl}$ at $\mathrm{pH} 2.5(3 \mathrm{~mL}$ $\left.\min ^{-1}\right)$; transition metals elution was performed with $12 \mathrm{M}$ $\mathrm{HCl}$. With Zn hyperaccumulating metallophytes ( $N$. caerulescens and A. vulneraria), Amberlite IRA 400 ion exchange resin was used for adsorption of $\mathrm{Zn}^{\mathrm{II}}$ on the resin, and elution of alkali and alkaline earth cations. Treatment with $0.5 \mathrm{M} \mathrm{HCl}$ eliminated a part of $\mathrm{Fe}^{\mathrm{III}}$ fixed on the resin before the elution of heavy metals $\mathrm{Zn}^{\mathrm{II}}$, $\mathrm{Cd}^{\mathrm{II}}, \mathrm{Pb}^{\mathrm{II}}$ with $0.005 \mathrm{M} \mathrm{HCl}$.

ICP-MS was used to determine the composition of the various plant extracts obtained. ICP-MS analyses were performed using the Metal Analysis of total dissolved solutes in water. The samples were acidified with nitric acid $2.5 \%$ and stirred for $30 \mathrm{~min}$. The digestates were diluted to $0.005 \mathrm{~g} \mathrm{~L}^{-1}$. Three blanks are recorded for each step of the digestion and dilution procedure on a HR-ICP-MS Thermo Scientific Element XR.

\section{Coupling of solid-supported $\mathrm{T}_{6}$ or RNA phosphoroimidazolidate with GDP}

Guanosine-5'-diphosphate sodium salt was converted before coupling into its tri- $n$-butylammonium salt as previously described. ${ }^{19}$ In a dry $2 \mathrm{~mL}$ microcentrifuge tube (Costar), bis(tri-n-butylammonium) GDP (103 $\mathrm{mg}, 0.14 \mathrm{mmol}$ ) and the freshly dehydrated catalytic extracts required for the coupling (0.2 mmol) whose amount was estimated from the concentration of the metal ( $\mathrm{Zn}$ or Ni) determined by ICP-MS (Table 1) were mixed in anhydrous DMF $(0.5 \mathrm{~mL})$. The tube was closed and the mixture was vortexed for $5 \mathrm{~min}$ on a Top-Mix 1118 (Fischerbrand) and centrifuged in a tabletop centrifuge (Sigma 1-13) at $6000 \mathrm{~min}^{-1}$ for $30 \mathrm{~s}$. This operation was repeated twice. The supernatant was taken using a glass syringe filled with 3 beads of $4 \AA$ molecular sieves. Using another syringe, the solution was applied to the column containing the solidsupported 5'-phosphoroimidazolidate oligonucleotide 3 (1 $\mu \mathrm{mol})$, and left to react for $18 \mathrm{~h}$ at $30{ }^{\circ} \mathrm{C}$. The solution was removed and the support was washed with water $(2 \times 2 \mathrm{~mL})$, then with a $0.1 \mathrm{M}$ aqueous solution of $\operatorname{EDTA}(\mathrm{pH} \mathrm{7,2} 2 \times 2 \mathrm{~mL})$, and dry $\mathrm{CH}_{3} \mathrm{CN}(4 \times 2 \mathrm{~mL})$. Finally the column was dried by blowing argon through it during $1 \mathrm{~min}$. The same procedure was applied for coupling with ${ }^{7 \mathrm{~m}} \mathrm{GDP}$ except a two-fold decrease in the quantities of reagents used.

\section{Conclusion}

This study clearly shows the interest of the metallophyte-based polymetallic catalysts for the synthesis of RNA 5 '-cap structures. They differ notably from classical systems which employ chemical uniformity and monometallic composition. Partial purification of the plant extracts was sufficient for catalytic performance. The polymetallic composition of our bio-based catalysts is particularly adapted to multi-step transformations, which are founded on different mechanisms and so required different catalytic effects. The coupling of the cap structure on DNA or RNA is illustrative for numerous issues in the development of a new concept for the "ecological" concept. Interestingly in the development of new "environmental" chemical processes it is noteworthy that this pyrophosphate bond formation was also the key point of an atom-economic methodology recently developed with the use of a ball-mill. ${ }^{25}$ Future developments of these plant-based catalysts are exciting, and can inspire the creativity of synthetic chemists. They constitute an important incentive for the development of phytoextraction and the subsequent polymetallic catalysis.

\section{Acknowledgements}

Y. Thillier thanks the Ministère National de la Recherche et de la Technologie for the award of a research studentship. The authors gratefully acknowledge financial support from the Agence Nationale de la Recherche (Opportunité (E) ${ }^{4}$ program), FEDER program and two Grants from the Ecole Polytechnique, Palaiseau and ADEME. The authors thank the Institut Agronomique Calédonien for the biomass harvests of $\mathrm{Ni}$ hyperaccumulating metallophytes.

\section{References}

1 V. Bert, P. Seuntjens, W. Dejonghe, S. Lacherez, H. T. T. Thuy and B. Vandecasteele, Environ. Sci. Pollut. Res., 2009, 16, 745-764.

2 W. R. Berti and S. D. Cunningham, in Phytoremediation of toxic metals: using plants to clean up the environment, ed. B. D. Ensley and I. Raskin, John Wiley \& Sons, New York, 1999, pp. 71-88.

3 L. L'huillier, T. Jaffré and A. Wulff, in Mines et environnement en Nouvelle-Calédonie: la revégétalisation des terrains miniers, 1st Ed, Institut Agronomique Calédonien, Nouméa, 2010.

4 B. H. Robinson, M. Leblanc, D. Petit, R. R. Brooks, J. H. Kirkman and P. E. H. Gregg, Plant Soil, 1998, 203, 47-56.

5 S. N. Whiting, R. D. Reeves, D. Richards, M. S. Johnson, J. A. Cooke, F. Malaisse, A. Paton, J. A. C. Smith, J. S. Angle, R. L. Chaney, R. Ginocchio, T. Jaffre, R. Johns, T. McIntyre, O. W. Purvis, D. E. Salt, H. Schat, F. J. Zhao and A. J. M. Baker, Restor. Ecol., 2004, 12, 106-116.

6 R. L. Chaney, Y. M. Li, S. L. Brown, F. A. Homer, M. Malik, J. S. Angle, A. J. M. Baker, R. D. Reeves and M. Chin, in Phytoremediation of Contaminated Soil and Water, ed. N. Terry, CRC Press, 2000, p. 408.

7 D. J. Glass, in Phytoremediation of toxic metals: using plants to clean up the environment, ed. B. D. Ensley and I. Raskin, John Wiley \& Sons, New York, 1999, pp. 15-32.

8 Y. M. Li, R. Chaney, E. Brewer, R. Roseberg, J. S. Angle, A. Baker, R. Reeves and J. Nelkin, Plant Soil, 2003, 249, 107-115.

9 M. Mench, N. Lepp, V. Bert, J. P. Schwitzguebel, S. W. Gawronski, P. Schroder and J. Vangronsveld, J. Soils Sediments, 2010, 10, 1039-1070. 
10 C. Grison and J. Escarré, PCT Int. Appl. 2011, WO 2011064487 and WO 2011064462.

11 G. Losfeld, V. Escande, T. Jaffre, L. L'Huillier and C. Grison, Chemosphere, 2012, 89, 907-910.

12 G. Losfeld, V. Escande, P. Vidal de La Blache, L. L'Huillier and C. Grison, Catal. Today, 2012, 189, 111-116.

13 S. Shuman, Prog. Nucleic Acid Res. Mol. Biol., 2001, 66, 1-40.

14 A. J. Shatkin, Cell, 1976, 9, 645-653.

15 A. E. Hodel, P. D. Gershon and F. A. Quiocho, Mol. Cell, 1998, 1, 443-447.

16 R. Zust, L. Cervantes-Barragan, M. Habjan, R. Maier, B. W. Neuman, J. Ziebuhr, K. J. Szretter, S. C. Baker, W. Barchet, M. S. Diamond, S. G. Siddell, B. Ludewig and V. Thiel, Nat. Immunol., 2011, 12, 137-143.

17 J. Jemielity, P. Heinonen, H. Lonnberg and E. Darzynkiewicz, Nucleosides, Nucleotides Nucleic Acids, 2005, 24, 601-605.

18 M. Kadokura, T. Wada, K. Seio, T. Moriguchi, J. Huber, R. Luhrmann and M. Sekine, Tetrahedron Lett., 2001, 42, 8853-8856.
19 Y. Thillier, E. Decroly, F. Morvan, B. Canard, J. J. Vasseur and F. Debart, RNA, 2012, 18, 856-868.

20 S. Mikkola, Z. Zhang, E. Mäki and H. Lönnberg, Curr. Org. Chem., 2005, 9, 1-23.

21 T. Lavergne, J. R. Bertrand, J. J. Vasseur and F. Debart, Chem.-Eur. J., 2008, 14, 9135-9138.

22 T. Lavergne, M. Janin, C. Dupouy, J.-J. Vasseur and F. Debart, in Current Protocols in Nucleic Acid Chemistry, ed. S. L. Beaucage, D. E. Bergstrom, G. D. Glick and R. A. Jones, John Wiley \& Sons, Inc., New York, 2010, vol. 43, pp. 3.19.11-3.19.27.

23 A. R. Martin, T. Lavergne, J.-J. Vasseur and F. Debart, Bioorg. Med. Chem. Lett., 2009, 19, 4046-4049.

24 A. Ohkubo, N. Tago, A. Yokouchi, Y. Nishino, K. Yamada, H. Tsunoda, K. Seio and M. Sekine, Org. Lett., 2012, 14, 10-13.

25 F. Ravalico, I. Messina, M. V. Berberian, S. L. James, M. E. Migaud and J. S. Vyle, Org. Biomol. Chem., 2011, 9, 6496-6497. 